Tommaso Greco. Associate Professor of Legal Philosophy at the Dipartimento di Giurisprudenza, Università di Pisa. Among his publications are: Norberto Bobbio: Un itinerario intellettuale tra filosofia e politica (Roma, 2000); La bilancia e la croce: Diritto e giustizia in Simone Weil (Torino, 2000); and Diritto e legame sociale (Torino, 2012). For the publisher Giappichelli, he directs the series "Bobbiana," which is re-releasing Norberto Bobbio's university lectures.

Contact: tommaso.greco@unipi.it 


\title{
THE REALITY OF RIGHTS. ON HORIZONTAL AND VERTICAL RELATIONSHIPS IN LAW
}

DOI: $10.17450 / 150210$

\author{
Tommaso Greco \\ Università degli Studi di Pisa
}

Reception date $23^{\text {th }}$ September 2015; acceptance date $18^{\text {th }}$ October 2015. This article is the result of a research project, held at the Dipartimento di Giurisprudenza (Università di Pisa).

\section{Abstract}

Despite many developments in recent decades, legal theory still seems prisoner to the positivist belief that only norms backed by state sanction can be deemed legal. The misgivings voiced concerning the notion of 'soft law' are evidence of this belief. This stance, which minimizes the significance of primary obligations, stems from the failure to take seriously the normative capacity of social relations, and thereby overlooks the foundational value that horizontal obligations have for the social and legal order. And in doing so, it risks misunderstanding the reality of rights, whose efficacy is guaranteed first and foremost through the mutual recognition between subjects in a relationship.

\section{Keywords}

Rights, obligations, guarantees, soft law, social bonds. 


\section{Resumen}

A pesar de las novedades de las últimas décadas, el pensamiento jurídico todavía parece preso en la creencia positivista que sólo lo que es fortalecido por la sanción jurídica del Estado puede tener valor jurídico. Algunas reticencias acerca del soft law son una manifestación de esta actitud, que disminuye la importancia de las obligaciones primarias, y que proviene del hecho de que no se toman en serio las consecuencias normativas de las relaciones sociales, olvidando la importancia que las obligaciones horizontales tienen para el orden social y jurídico. De esta manera, no se puede comprender la realidad de los derechos, cuya eficacia está garantizada principalmente por el reconocimiento mutuo entre los sujetos de las relaciones.

\section{Palabras clave}

Derechos, deberes, garantías, soft law, vínculo social.

\section{Horizontal Law}

For the past few decades, legal theory has abandoned formalism and rediscovered harmony with values and facts. ${ }^{1}$ Despite many advances, however, it has been difficult to elude the view that considers fully 'legal' only what is produced, mediated, and 'reinforced' by the state. An example of this can be seen in the area of soft law. Of course, this type of law is recognized as an important development in the traditional model of regulation; it is understood to have the capacity to produce practical effects; it is even recognized to possess legal status; and yet it is often held that soft law is a normative artifact that is non-binding, as if only norms buttressed by the coercive structures of the state ought to be considered binding. ${ }^{2}$

\footnotetext{
1. Among the many references possible, see G. Minda, Postmodern Legal Movements. Law and Jurisprudence at Century's End, New York University Press, New York and London, 1995; M. Del Mar (ed.), New Waves in Philosophy of Law, Palgrave Macmillan, London-New York, 2011; F. Viola-G. Zaccaria, Le ragioni del diritto, il Mulino, Bologna, 2003; P. Grossi, Ritorno al diritto, Laterza, Roma-Bari, 2015.

2. One of the contributions most willing to admit the fully legal nature of soft law is B. Pastore, Interpreti e fonti nell'esperienza giuridica contemporanea, Cedam, Padova, 2014, p. 103 and ss. But even this author speaks of "rules of conduct that, in principle, do not possess legally binding force" (p. 106), of acts "that exclude a strict binding discipline" (p. 109), of a "written law that is not prima facie obligatory" (p. 117). By the same author, see also "Soft Law y la teoría de las fuentes del derecho", in Soft Power, 1, 2014, pp. 75-89.
} 
In my view, this occurs because legal theory seems unable to take seriously not only the theme of social relations, but more importantly the notion of their normative capacity. Among other things, this theoretical disposition impedes efforts to understand the concrete reality in which subjective rights arise, operate, and continuously develop. It is inconceivable that the conceptual link between the theory of rights is entirely detached from the texture of social relations in which we move every day. Likewise, it is inconceivable that the living law can operate independently (or against) the fabric of social relations.

The thick social fabric I am referring to - composed of relationships of all kinds, including family, friends, economic, and professional - is the terrain upon which the horizontal dimension of law and rights can be found. We will explore what I mean by this below. But for now, it may be worthwhile to specify that what I mean by horizontal are the relationships between subjects that are not mediated by an institution. A relationship is horizontal (not vertical) if the objective of the relationship is met by virtue of the direct action produced by the subjects of that relationship. When the intervention of a third party is sought - such as a judge or the police - the relationship ceases to be horizontal and it takes on a vertical connotation.

Thus what differentiates these two modalities of law is not the fact that one is binding while the other is not; rather, it is the fact that in these modalities the obligatoriness (and therefore the efficacy) of law is obtained in different ways. In the hard and vertical, this occurs through the (threat of) coercion. In the soft and horizontal, it occurs through the spontaneous fulfillment of obligations by the subjects participating in the relationship. If in the latter case we speak of a soft bindingness, it is only because the coercive structures of the state are not brought to bear upon the interaction. But this does not make the obligations in question any less legal, much less their fulfillment. On the contrary, this is the principal way in which the law carries out its regulative function on a daily basis.

To this point, it should be understood that the use of the term 'horizontal' appears here in a significantly different light than it does when one speaks of the 'horizontal efficacy of rights' in legal science. The latter, which is known in the European debate as Drittwirkung, involves the possibility of invoking the application of fundamental rights within relationships between private individuals; that is to say, within relationships disciplined by the norms of private law. ${ }^{3}$ To 'invoke' means asking a judge to apply these

3. See, e.g., V. Colcelli, Le situazioni giuridiche soggettive nel sistema CEDU, Iseq Gioacchino Scaduti, Perugia, 2010, p. 36. 
rights, and seeing to it that their application produces the effects directly in the relationship between private parties. But this 'invocation' is located along the vertical axis, not along the horizontal one. This is what I will attempt to clarify in what follows.

My thesis can be summarized therefore in the following way: there is a horizontal - relational - dimension that belongs to the law and to rights. This dimension: a) is autonomous with respect to the vertical dimension; b) should be considered fully legal and not merely moral or social; c) can boast a legal nature that is based on the correlation between rights and duties.

\section{Law and Social Relations}

The following argument must first be situated within a general framework of the relationships between law and social relations - relationships whose theoretical background can be summarized with reference to two models. ${ }^{4}$ On the one hand, there is the ancient or Aristotelian model that understood social relations to be independent of law. Aristotle's notion of man as a "political animal" allowed for the creation of the city and order upon the basis of the concept of philia or political friendship. In this model, law is necessary only where bonds between people do not function, and an individual is unable to behave out of "friendship." The other model is the modern one that culminates in the theories of Thomas Hobbes. This time, however, social relations are not only not autonomous with respect to law, but are completely subsumed within the law. It is law that constitutes the relationships, and in constituting them, it substitutes for them.

Both of these models are defective insofar as they conceptualize law and social relations as alternatives; where there is one, the others are absent, and vice versa. They are based on a binary scheme, and the distinction to which they refer is a 'strong' distinction. But can law and social relations be understood as two things that imply one another? Are legal relationships possible that are at once social and include a legal dimension?

There is a current of legal theory that seems to help in this regard. I am referring to all the theories that criticized state-centered and coercion-centered reductionism, and which insisted on the social nature of the legal phenomenon. Anti-formalistic theories and anthropological approaches to the law have both maintained that law is first and

4. For a more detailed account of this reading of the history of legal thought, see my Diritto e legame sociale, Giappichelli, Torino, 2012. 
foremost a social phenomenon, which means that it obtains - prior to its formalization in a structure of power - within the relationships between subjects and groups. This is not the place to enter into the details of these theories. ${ }^{5}$ Suffice it to say that these views allow for the development of an alternative model to the two classic models mentioned above. In this model, law and social relationships do not occupy two distinct and opposing fields; rather, it is possible to identify a continuous line between the two. At the extremes there are, to be sure, relationships without law (e.g., those based on love) and law without social relationships (coercive law). But at intermediate points between these extremes it is possible to identify social relationships that are also legal relationships.

It must be noted that even positivist theory of law in the latter half of the twentieth century moved in this direction. This theory is notable for its search for new avenues with respect to earlier theories that considered (positive) law as the command of a sovereign. Here I am reminded of the theories of Herbert H.L. Hart and his attempt to understand the nature of law by separating it not only from morality, but from coercion as well. ${ }^{6}$ This aim led him to take into consideration an aspect of law that had remained hidden in previous legal theories, namely, law's "acceptance", which was implied in what Hart called "rule of recognition."

The presence of this rule - whose acceptance, for Hart, indicates the adoption of the internal point of view - allows us to see that "laws function in their lives not merely as habits or the basis for predicting the decisions of courts or the actions of other officials, but as accepted legal standards of behavior. That is, they [the individuals] not only do with tolerable regularity what the law requires of them, but they look upon it as a legal standard of conduct, refer to it in criticizing others, or in justifying demands, and in admitting criticism and demands made by others."

Thus the fabric of legal actions that Hart identifies is nothing other than a thick fabric of legal relationships within which diverse subjects put into play their mutual expectations.

With regard to legal relationships, therefore, we may speak - as the Italian legal philosopher Sergio Cotta did - of a "real possibility of understanding and collaboration" that is established between participants in the relationship. It is important to under-

5. I surveyed these theories in the essay "Le teorie antiformalistiche e l'istituzionalismo giuridico", in Prospettive di filosofia del diritto del nostro tempo, Giappichelli, Torino, 2010, pp. 181-217. The basic text on anti-formalist theories is L. Lombardi Vallauri, Saggio sul diritto giurisprudenziale, Giuffrè, Milano, 1967.

6. See H.L.A. Hart, The Concept of Law (1961), Second Edition with a Postscript edited by P.A. Bulloch and J. Raz, Clarendon Press, London, 1994.

7. Ibid., pp. 137-138.

8. S. Cotta, Il diritto nell'esistenza. Linee di ontofenomenologia giuridica, Giuffrè, Milano, 1985, p. 50. 
score that, even in the case of two unknown parties who engage one another in order to carry out a transaction (such as purchase agreement), we are observing a movement that is conjunctive rather than disjunctive. Even if each party fulfills his obligations in order to satisfy his own good and goals, each individual must necessarily take heed of the expectations of the partner.

The legal relationship, therefore, far from being a non-relationship, is a relationship that instantiates within the law a kind of recognition and "acceptance" of the other, however minimal. Instead of representing a space of total immunization of the relationship, ${ }^{9}$ law can constitute a way of relating that is not only entirely compatible with, but indeed fruitful for social relations.

\section{Horizontality and Verticality in the Guarantee of Rights}

The best way of understanding the nature of the distinction between horizontal (soft) normativity and vertical (hard) normativity is to see what role 'horizontality' plays in the field of rights. Subjective rights, more than other legal 'objects,' are interpreted often as something unimaginable outside of a jurisdictional relationship, and therefore outside of the vertical dimension. Naturally, this is a fundamental dimension of rights, and it is worth stating this immediately and without hesitation. The 'jurisdictionalization' is precisely what allows rights (and law in general) to prevent social relationships from being based on subordination and de facto power. ${ }^{10}$ To use the classic, but effective play on words: the force of law is necessary to avoid the imposition of the law of force. Rights are part of this game and carry out an essential role.

Nevertheless, neither the function nor the structure of rights is exhausted in the possibility of bringing a legal claim. I will attempt to explain why, and to do so, there is no better place to start than with the work of Luigi Ferrajoli.

Ferrajoli's theory is important for many reasons, not least of which is that it shows that any attempt - no matter how strenuous - to separate rights from their corresponding obligations is destined to fail. In fact, Ferrajoli's argument shows us that whenever a subject's right is recognized, at that very moment obligations arise for others. As Ferrajoli explains so well, this is inevitable; for if an individual issuing a right has forgotten

9. On law as a "function of the immunitary mechanism" the key work is R. Esposito, Immunitas. The protection and Negation of Life, Polity Press, Cambridge (UK), 2011.

10. See E. Ripepe, "Sulla tutela dei diritti fondamentali", in E. Ripepe, Riforma della Costituzione o assalto alla Costituzione? (e altre riflessioni in pubblico), Cedam, Padova, 2000, pp. 171 and ff. 
to identify the subjects of the primary and secondary obligations, he himself will be obliged to fill the gap created in the omission. ${ }^{11}$

But let us explore how and why Ferrajoli's theory is helpful - even in the light of certain criticisms we will adumbrate - in bringing out the autonomy of the horizontal guarantees.

In many writings in recent years, Ferrajoli distinguishes two types of guarantee: primary and secondary. The former consist in the set of obligations elicited in certain subjects; those obligations correlate with the positions of the rights-holder. Secondary guarantees, by contrast, come into play when the primary guarantees have been ignored or violated by those who were obliged to comply with them; these guarantees consist in sanctioning and judicial mechanisms made available by the legal system as a last resort protection of subjective rights. ${ }^{12}$

This dual guarantee can certainly be interpreted as a clear demonstration of the fact that the horizontal dimension lives side-by-side with (but at the same time is autonomous from) the vertical dimension.

It is important to note that even Ferrajoli uses the terms "horizontal" and "vertical", but he uses them in a different way than the one being employed here. He distinguishes horizontal and vertical guarantees "according to whether the subjects with which the claim-holders engage are private or public." 13

This way of characterizing the distinction leads to the notion that "horizontal relationships between private individuals" are "those that form the fabric of market relations in the civil sphere", while "vertical relationships between citizens and the public sphere" are "those upon which political obligations are based." ${ }^{4}$ This distinction mirrors the one made between public and private spheres, which are tasked, respectively, with the protection of fundamental rights and general interests or the protection of property rights and particular interests.

The usage of these terms proposed by Ferrajoli is flawed insofar as it identifies horizontal legal relationships with economic relationships, leading us to believe that, when property rights are in play, a direct (horizontal) relationship is possible only in the sphere of action populated by homo aconomicus. On the other hand, it compresses the complex fabric of obligations pertaining to fundamental rights within the

11. Among Ferrajoli's many works, here we are referring to the book that represents the summa of his thought: Principia Iuris. Teoria del diritto e della democrazia. Vol. I. Teoria del diritto, Laterza, Roma-Bari, 2007, p. 675.

12. Ibid., p. 668.

13. Ibid., p. 369.

14. Ibid. 
structure of secondary guarantees - a relationship that is indeed exclusively public and vertical.

In my view, what determines the direction of the relationship is not the private or public context, but rather the fact that the purposes of the rights may be produced within the relationship, or through an appeal to the legal system.

If the primary guarantees consist in obligations elicited in subjects who find themselves in some kind of relationship with the holder of a right, this means that there is a direct relationship between the subjects involved who interact without the mediation of an institutional subject. Even when we are talking about obligations that pertain to formalized and institutionalized 'public' relationships (e.g., a doctor who must provide necessary treatment to guarantee his patient's right to health), at the center of the legal relationship there is an immediate and direct relationship between the holder of the right and the bearer of the corresponding obligation. The satisfaction of the right-holder's expectations vis-à-vis other subjects depends, at this stage, exclusively upon the behavior of the latter.

Therefore the distinctiveness of the primary guarantees is the following: by bringing two subjects into relation with one another, they establish a connection that implies a necessary act of recognition on the part of the subject who must fulfill his specific obligations with regard to the right-holder. It is the holder of the obligations (primary guarantees) who can or must guarantee the efficacy of the right.

The situation in which secondary guarantees are activated is much different. At this stage, the original relationship is transformed and becomes mediated by an institutional subject, called into cause precisely to remedy the pathology introduced in the first-degree relationship. To appeal to the secondary guarantee means, therefore, not so much that the relationship between subjects involved in the primary relation has diminished, but that this relation has taken on a new direction and a different structure.

When there is a violation of primary obligations, the rights-holder expects to obtain justice, and the secondary guarantee comes into play precisely to remedy the failure of compliance on the part of the subject who bore the obligation. It is here that the relationship changes nature and orientation: what is horizontal becomes vertical, and this changes the direction of the relationship between the subjects involved. The soft becomes hard. Now, the relationship is mediated by a third party - the judge - who maintains this position just as long as necessary to satisfy the right. 


\section{Is Horizontal Law Binding?}

The fact that, in certain cases, protecting a right requires triggering the secondary guarantee does not mean that the primary guarantees are meaningless. There are empirical reasons that confirm this; in the majority of cases, we obey rules that we are bound to obey in the various spheres of our life without even thinking that, were we not to, we would end up in front of a judge who could sentence us. ${ }^{15}$ We do it - end of story.

But this is not the kind of argument that we can rely upon here; we need logical and theoretical arguments. The fact that secondary guarantees - call them hard, if you will are what complete a subjective right cannot be a sufficient reason to deny the substance of the primary (soft) guarantees. The greater certainty that the secondary guarantees purportedly bring does not occlude the autonomy of the primary guarantees, for shifting all of the responsibility onto the secondary guarantees would be to conflate once again two things that are conceptually distinct, namely "to have an obligation" and "to feel obligated." This distinction seems necessary, as Hart argued, if we want to avoid conflating law with force. In fact, Hart maintained,

We must not allow them to trap us into a misleading conception of obligation as essentially consisting in some feeling of pressure or compulsion experienced by those who have obligations. The fact that rules of obligation are generally supported by serious social pressure does not entail that to have an obligation under the rules is to experience feelings of compulsion or pressure. Hence there is no contradiction in saying of some hardened swindler, and it may often be true, that he had an obligation to pay the rent but felt no pressure to pay when he made off without doing so. To feel obligated and to have an obligation are different though frequently concomitant things. To identify them would be one way of misinterpreting in terms of psychological feelings, the important internal aspect of rules. ${ }^{16}$

In this regard, we might recall Rousseau's clear statement: "But what kind of right perishes when might disappears? If one is compelled to obey by force, there is no need to obey from duty; and if one is no longer forced to obey, obligation is at an end." 17

\footnotetext{
15. This is one of the arguments in a classic work in the sociology of law: E. Ehrlich, Fundamental Principles of the Sociology of Law (1913), Transaction Publishers, New Brunswick/London, 2002.

16. H.L.A. Hart, The Concept of Law, p. 88.

17. J.-J. Rousseau, The Social Contract (1762), I.III, in J.-J. Rousseau, The Social Contract and The First and Second Discourses, edited and with an introduction by S. Dunn, Yale University Press, New Haven-London, 2002, p. 158.
} 
This suggests therefore that we evaluate the primary guarantees from the standpoint of a normative argument, not merely a factual one.

On the other hand, the temptation to reduce the primary guarantees to the secondary ones - and thus to subsume the horizontal in the vertical - is quite understandable. This derives from the conviction that the fundamental element of rights is their justiciability. The 'protection of the right' thus is considered a constituent element of the right itself. Alf Ross has put this point plainly:

"Since a claim in its legal function is identical with opportunity of obtaining judgment against the person who is in duty bound, the procedural protection of a right is merely another side of the content of the right. A claim is nothing without the sanction of the machinery of the law." 18

We might say that the truth (or spirit) of subjective rights resides in the possibility of activating judicial protections.

I believe, however, that reductionism with regard to guarantees has primarily an extra-juridical origin that can be traced back to concerns of an anthropological nature. Such a view is advanced, for example, by Ferrajoli himself, who writes in his important work Principia Iuris:

What all guarantees have in common is precisely the fact that in their absence, the right that they express would be violated and therefore ineffective; it is a sort of lack of confidence in their spontaneous satisfaction or spontaneous respect for rights, and specifically, as far as fundamental rights are concerned, in the spontaneous exercise of legitimate power. The defense of rights, in this sense, is opposed to any conception of political or economic relationships - as well as public or private law - that is based on the dreamlike idea of 'good power' or the spontaneous observance of law and rights. ${ }^{19}$

The argument has an implicit but unmistakable Hobbesian flavor. Here what is being claimed is not merely that the fulfillment of primary obligations is motivated always by the possibility (and the threat) that the rights-holder use secondary guarantees; what

18. A. Ross, On Law and Justice, University of California Press, Berkeley-Los Angeles, 1959, § 38, p. 184. 19. L. Ferrajoli, Principia Iuris, pp. 195-196. 
is being claimed is that trust has no place in law, as if law must resign itself to "incorporate not trust but only its disappointment." ${ }^{20}$ Horizontality in this sense is considered only as a risk, or even as a threat, but never as a resource.

Naturally, there can be no doubt about the fact that primary guarantees are reinforced by secondary guarantees; just as there can be no denying the fact that it is the very presence of secondary guarantees that makes subjective rights 'whole.' Nonetheless, the foregoing should not lead us to conclude that the horizontality of obligations - and what this horizontality signifies for the definition and functioning of the fabric of rights - is logically precluded. In other words, to claim that it is necessary to supply secondary guarantees that compensate for unfulfilled primary obligations is not to claim necessarily that the latter lack an autonomous normative force. To make such a claim would be to engage in a sort of question-begging, according to which one demonstrates that what is given by definition is taken to be true. In this case, the concern for the certainty in the fulfillment leads one to deny autonomy to the primary guarantees, since it is believed that parties to the interaction are unable to spontaneously observe obligations. Thus the only normative force recognized is one that derives from the looming threat of sanction. Those rights believed to be 'sweet fruits' can only be produced, in this view, by obligations that are seen as 'bitter fruits' that are imposed through coercion. But this is precisely what Hart was trying to avoid with the aforementioned distinction between "feeling obliged" and "having an obligation."

To keep the horizontality of obligations - to affirm, in other words, that there is a soft normativity that stems from the reciprocal recognition that is established between subjects, and which precedes (and in large part renders moot the intervention of) hard normativity - is one way of underscoring that the force of rights derives from primary guarantees, not merely from secondary ones. To this end, what is required is to take seriously the obligations that constitute the primary guarantees, and to see them as binding in virtue of the fact that they exist, not because there is a sanction looming to enforce them. This is the only way to attribute to them autonomy on the legal level. In other words, we are not here invoking the factual argument concerning spontaneous acceptance, but rather the normative argument concerning the existence of obligations in the conscience of specific subjects.

To be sure, do not we do the same thing when it comes to secondary guarantees? When we speak of the 'existence of secondary guarantees' are not we suggesting the

20. E. Resta, Le regole della fiducia, Laterza, Roma-Bari, 2009, p. 8. 
simple possibility of being able to count on a legal remedy, rather than on the effective implementation pursuant to a ruling? And so why, then, is not it enough to point to the possibility of counting on their fulfillment for them to be considered fully legal?

\section{Taking obligations seriously}

Framing the matter in this way does not seem very attractive, insofar as it explicitly shifts the attention toward the responsibility of the subjects who are called upon to fulfill their obligations, and upon whom the burden falls to provide the goods that form the content of the rights. ${ }^{21}$ But despite its lack of appeal, we all know that no right can be effective if it does not have the respect of at least a relevant part of the society in which it is in force. Certainly, there are problematic cases regarding those rights that have not yet been fully accepted in the social consciousness; in these cases, no doubt, the secondary guarantees come into play more often. But the fact that violations of those rights are perceived as an injustice tells us how important they achieve the very recognition that would constitute a primary (and more secure) guarantee.

The recovery of obligations allows us to save - or appreciate - the relational dimension of rights without dissolving it into the coercive structure of the legal system. The Hobbesian sting - according to which every pactum unionis must necessarily be absorbed by the pactum subiectionis or risk its very existence - is neutralized and no longer necessary. In this way, thanks to the 'bridge' provided by the horizontal nature of primary guarantees, it seems possible to go beyond the dichotomy between communitas and immunitas, that is to say, a space constituted exclusively by relationships based on munus and a space that is entirely 'neutralized' thanks to law. ${ }^{22}$ The more primary obligations are taken seriously, together with the direct motivation that pushes for their respect, the more the social and socializing (rather than immunizing) dimension of rights will be accepted. Naturally, we should not think that the dynamic of rights and obligations can in itself constitute (or substitute) for the richness of the social bond.

21. Cfr. E. Bea Pérez, “Derechos y deberes. El horizonte de la responsabilidad”, in Derechos y libertades, 29, 2013 , pp. 53-92. 22. Here we are referring to the work of R. Esposito, Communitas. The Origin and the Destiny of Community, Stanford University Press, Stanford, 2010; Id., Immunitas. For an interpretation of rights as an instrument of immunization of social relationships, see also P. Barcellona, Il ritorno del legame sociale, Bollati Boringhieri, Torino, 1990, pp. 109 and ss. I agreed with this interpretation in my essay "Prima il dovere. Una critica della filosofia dei diritti", in S. Mattarelli (ed.), Doveri, Franco Angeli, Milano, 2007, pp. 15-30. 
Beyond the socializing value that even rights can possess - thanks to the link provided by the primary obligations that are invoked to render them effective - what must be underscored in conclusion is that the boundary between the primary and secondary guarantees does not represent the distinction between what is legal and what is not legal. It represents - within the law - the boundary between horizontality and verticality, between soft guarantees and hard ones, between a legality that is based on the observance of duties and obligations on the part of subjects and a legality that must appeal to threats and sanctions to be effective.

If this is the case, we cannot continue to believe that a soft legality is inferior to a hard one. We must rather recognize that reality is stronger than the theories that we employ to decode it, and with which we sometimes mistake it.

Translation by Aaron Thomas 